\title{
How not to act on good advice
}

As European countries engage in diplomatic battle over the banned exports of British beef and its products, lessons can be drawn from the sorry history of the British government's selective responses to expert advice.

RARELY has the word 'science' passed a politicians lips more frequently than it did last week when John Major, Britain's Prime Minister, told the House of Commons of his plans to retaliate against Europe's refusal to lift a ban on beef by-products. But then, rarely has an issue presented in starker form the morass created when science and politics collide over perceptions of risk. If there are lessons to be learnt from the crisis in the UK beef industry over the bovine spongiform encephalopathy (BSE) epidemic, one is the continued need for responsible ways of handling scientific uncertainty. It is precisely the failure of the British government to do this that has created its current plight.

The act that generated Major's indignation - and has stirred a jingoistic ground-swell in Britain against its European partners - was the refusal of the European Union (EU)'s Standing Veterinary Committee to recommend lifting a ban on the exports of tallow, gelatine and bull semen (see page 353). Formally, the role of the committee, made up of veterinary experts representing the EU's 15 member states, is to provide professional advice on human and animal health. Last week, however, there were few attempts to disguise the extent to which the seven members of the committee who voted against lifting the ban each had broader considerations on their minds than the safety of the product. Britain's chief opponent was Germany, whose demand that British beef be shown to be "completely safe" before any ban is lifted may be unrealistic, but reflects widespread popular concern about 'unnatural' contamination of the food chain.

Whatever the specific reasons, there is plenty to substantiate the criticism of the committee's decision made by Major's beleaguered agriculture minister, Douglas Hogg, that "the language of science has been used to advance political objectives". Nor would many quarrel with Hogg's subsequent suggestion that, "when forming policy, it is extremely important to follow the science". Indeed, the British government has been at pains to emphasize in recent weeks that it has repeatedly followed the suggestions of its scientific advisers.

Speaking literally, the government is correct; most of its advisers' specific conclusions have been acted on. But this argument misses a wider point. Public confidence in today's sophisticated and media-rich world is no longer based on uncritical acceptance of 'scientific' statements - however prominent those who make them - but on a more complex process that hinges on the question of trust. Here, things have gone badly wrong.

The government, for example, accepted immediately the proposal of an earlier advisory committee in the late 1980 s, chaired by Sir Richard Southwood, professor of zoology at the University of Oxford, on the need to eliminate beef from BSE-infected cattle from the human food chain. But Germany's stance last week was a reflection less on the British government's intentions than on the effectiveness with which they have been pursued.

There have, in particular, been continued and serious gaps in safety practices in the meat-processing industry. As British ministers recently admitted, spot checks on slaughterhouses carried out as recently as the past nine months have found 25 instances in which pieces of spinal cord had been left attached to carcasses; in at least one case, the entire spinal cord was left attached. During the same period, 12 officials of the Meat Hygiene Service have been given formal disciplinary warnings for their failure to ensure full compliance with controls on 'specified bovine material'.

Indeed, there is considerable evidence that, if the Southwood committee's broader warnings - and not merely its oversimplified conclusions - had been taken more seriously at the time by both the government and the beef industry, neither would be in the plight it is today. A paper published in Nature earlier this month $(\mathbf{3 8 1}, 119 ; 1996)$ pointed to the damning fact that almost three-quarters of the $29,000-40,000$ cattle likely to develop BSE over the next five years were born after the 1989 ban on feeding animal protein to cattle. One conclusion is that the ban was ignored by some farmers and inadequately policed by the government.

Part of the blame for this must be placed on the political spin given to the Southwood committee's main conclusion - that the chances of humans contracting CJD from BSE were "remote". It took little for John Gummer, the then agriculture minister, to turn this - with the backing of Mrs Margaret Thatcher, the then prime minister - into the assertion that beef was "absolutely safe". One result was to encourage a complacency in the beef industry that played down the severity of the BSE problem. Another was to weaken political support for those demanding a crash programme of research into the possible relationship between BSE and CJD, despite Southwood's secondary conclusion that transmission to humans could not be ruled out, and could prove to be "extremely serious".

The government's announcement last week that an additional $£ 8.5$ million is being made available for research by the ministries responsible for agriculture and health implies that this view is (now) shared, albeit in reaction to European pressure. But two tasks still remain. One is a close analysis of the way the warnings of possible long-term health risks - however unlikely expressed by several respected scientists in the late 1980s appear to have been submerged by a political desire to capitalize on a more simplistic interpretation of its conclusions. This issue strikes at the core of the relationship between government and its scientific advisers, on issues ranging from the deep-sea disposal of the Brent Spar to the safety of radioactive waste. If politicians wish to use the conclusions of scientists to legitimize their decisions, they must be prepared to listen to the full message they are given, not merely isolate those parts that support their own agenda.

As for the beef crisis itself, the British government must now demonstrate the scientific validity of any proposed course of action - in particular, the reasoning behind the strategy it eventually adopts for deciding which cattle should be culled in order to eliminate BSE. It must also gain the confidence of its European partners both in the robustness of its calculations and in its determination to apply them effectively.

Science has little to say on the second of these. On the first, much would be gained if the process were opened up to the scrutiny of an international, politically independent panel, particularly given the continuing uncertainties involved. This could include members nominated by the scientific academies of European and other countries - perhaps modelled on the US National Research Council - and should be guaranteed open access to all relevant medical and veterinary data. 